\title{
Pengaruh Kepadatan Kandang terhadap Konsumsi Ransum, Konversi Ransum dan Pertambahan Berat Badan Harian (PBBH) Ayam Broiler
}

Arnoldus Y. Meke ${ }^{\mathrm{a}}$, dan Stefanus Sio ${ }^{\mathrm{b}}$

${ }^{a}$ Fakultas Pertanian, Universitas Timor, Kefamenanu, TTU - NTT, Indonesia, email: nolinmeke@ gmail.com

${ }^{b}$ Fakultas Pertanian, Universitas Timor, Kefamenanu, TTU - NTT, Indonesia, email: Stefsio67@ gmail.com

\section{Article Info}

Article history:

Received 7 Maret 2018

Received in revised form 10 April 2018

Accepted 19 April 2018

https://doi.org/10.32938/ja.v3i2.410

Keywords:

Kepadatan Kandang

Broiler

\section{Abstrak}

Tujuan penelitian ini untuk mengetahui pengaruh kepadatan kandang terhadap konsumsi ransum, konversi ransum dan PBBH ayam broiler. Penelitian dilaksanakan pada bulan Januari sampai Februari 2018. Kandang komunal tipe lantai yang dibagi dalam 3 blok di man tiap blok terdiri dari $5 \mathrm{~m}^{2}$, sehingga total keseluruhannya adalah $15 \mathrm{~m}^{2}$. Kandang dibuat dengan menggunakan bambu sebagai batas antara tiap $\mathrm{m}^{2}$. Setiap $\mathrm{m}^{2}$ dilengkapi dengan tempat makan dan minum dan ternak ditempatkan sesuai perlakuan; $\mathrm{R} 0=\mathrm{Kepadatan} 4 \mathrm{ekor} / \mathrm{m}^{2}, \mathrm{R}$ = Kepadatan 5 ekor $/ \mathrm{m}^{2}, \mathrm{R} 2$ = Kepadatan $6 \mathrm{ekor} / \mathrm{m}^{2}$. Lantai kandang ditaburi dengan kapur agar mengurangi dampak pertumbuhan mikroorganisme pembusuk dan juga bau amonia, diikuti dengan pemberian sekam padi dengan ketebalan $5 \mathrm{~cm}$ sebagai liter. Kandang dan peralatan kandang disucihamakan dengan desinfektan. Variabel yang dilihat adalah konsumsi ransum, pertambahan berat badan, dan konversi ransum. Rancangan Acak Lengkap (RAL) yang terdiri dari 3 perlakuan dan 5 ulangan. dan data yang diperoleh dianalisis dengan menggunakan menggunakan software SAS versi 9.1. Dapat disimpulkan bahwa konsumsi ransum dan pertambahan berat badan terbaik adalah pada kepadatan kandang 5 tertinggi $5 \mathrm{ekor} / \mathrm{m}^{2}$ dan konversi ransum terbaik adalah pada kepadatan kandang $6 \mathrm{ekor} / \mathrm{m}^{2}$.

\section{Pendahuluan}

Ayam Broiler merupakan ternak yang sangat efisien menghasilkan daging selain itu ayam Broiler memiliki keunggulan lebih cepat proses pemeliharaannya untuk dipanen dibandingkan ayam kampung. Menurut Rasyaf (2006) ayam broiler merupakan salah satu jenis ternak unggas hasil rekayasa manusia yang telah mengalami seleksi gen selama bertahun-tahun sehingga hanya dalam waktu 21 sampai 40 hari sudah layak di konsumsi dan ketika berumur 8 minggu ayam broiler di jual dengan berat tubuh tertentu serta mempunyai dada lebar dengan timbunan daging yang banyak. Jadi ayam yang pertumbuhannya cepat itulah yang dimasukkan dalam kategori ayam pedaging atau broiler

Pertumbuhan dan perkembangan ternak merupakan proses fisiolog hewan yang dipengaruhi oleh berbagai faktor seperti pola pemeliharaan, lingkungan, pakan, kesehatan. Untuk meningkatkan pertumbuhan broiler maka ada beberapa faktor penting yang perlu di perhatikan salah satu diantaranya adalah kepadatan kandang. Rasa nyaman (comfortable) ternak dalam kandang dipengaruhi oleh tingkat kepadatan. Nuriyasa \& Astiningsih (2002) menyatakan semakin tinggi kepadatan ternak dalam kandang semakin banyak pula panas dan uap air yang dilepaskan ke lingkungan kandang.

Tujuan penelitian ini untuk mengetahui pengaruh kepadatan kandang terhadap konsumsi ransum, konversi ransum dan $\mathrm{PBBH}$ ayam broiler.

\section{Metode}

Penelitian ini berlangsung pada di kandang broiler milik Program Studi Peternakan, Fakultas Pertanian, Universitas Timor di Kelurahan Sasi, Kecamatan Kota Kefamenanu, Kabupaten Timor Tengah Utara. Penelitian berlangsung selama 5 minggu pada bulan Januari sampai Februari 2018. Peralatan yang digunakan dalam penelitian ini antara lain kandang komunal tipe lantai yang dibagi dalam 3 blok di mana tiap blok terdiri dari $5 \mathrm{~m}^{2}$, sehingga total keseluruhannya adalah $15 \mathrm{~m}^{2}$. Kandang dibuat dengan menggunakan bambu sebagai batas antara tiap $\mathrm{m}^{2}$. Lantai kandang ditaburi dengan kapur agar mengurangi dampak pertumbuhan mikroorganisme pembusuk dan juga bau amonia, diikuti dengan pemberian sekam padi dengan ketebalan $5 \mathrm{~cm}$ sebagai liter.

Kandang dan peralatan kandang disucihamakan dengan desinfektan Setiap $\mathrm{m}^{2}$ dilengkapi dengan tempat makan dan minum. Timbangan dengan kapasitas $2 \mathrm{~kg}$, dengan tingkat ketelitian 1gram untuk menimbang ternak dan pakan, alat pemanas berupa bola lampu 75 watt, termometer, peralatan kebersihan kandang dan alat tulis menulis.

Ternak yang digunakan adalah DOC sebanyak 100 ekor yang telah divaksin sedangkan pakan yang diberikan adalah pakan komersial (BR1 dan BR2). Rancangan yang di gunakan dalam penelitian ini Rancangan Acak Lengkap (RAL) yang terdiri dari 3 perlakuan dan 5 ulangan. Setiap uni percobaan terdiri dari satu $\mathrm{m}^{2}$ kandang di mana setiap $\mathrm{m}^{2}$ diisi dengan jumlah ternak sesuai perlakuan. Adapun perlakuan yang diuji adalah : R0 = Kepadatan 4 ekor/m2, R1 = Kepadatan 5 ekor $/ \mathrm{m}^{2}, \mathrm{R} 2=$ Kepadatan 6 ekor $/ \mathrm{m}^{2}$. Variabel yang dilihat adalah konsumsi ransum, pertambahan berat badan, dan konversi ransum. Data yang di peroleh dianalisis dengan menggunakan menggunakan software SAS versi 9.1

\section{Hasil dan Pembahasan}

\subsection{Konsumsi Ransum (g/e/hr)}

Konsumsi ransum merupakan jumlah ransum yang dikonsumsi dalam jumlah waktu tertentu yang akan di gunakan oleh ternak untuk memenuh kebutuhan hidup dan zat makan lainnya semakin hari ayam bertumbuh maka semakin banyak ransum yang dikonsumsi oleh ayam. Pemberian ransum bertujuan untuk menjamin pertumbuhan berat badan dan menjamin produks daging agar menguntungkan (Sudaro \& Siriwa, 2007). Data rataaan konsumsi ransum dapat dilihat pada Gambar 1 .

Gambar 1. menunjukkan bahwa konsumsi ransum tertinggi pada semua perlakuan terjadi pada perlakuan R1 diikuti perlakuan R2 dan yang paling rendah adalah perlakuan R0. Hasil analisis sidik ragam menunjukkan bahwa pengaruh perlakuan kepadatan kandang terhadap konsumsi ransum baik pada minggu sampai ke 5 menunjukkan berbeda tidak nyata $(\mathrm{P}>0,05)$ atau dengan kata lain bahwa antar tingkat kepadatan 4, 5 dan 6 ekor/m2 memiliki tingkat konsumsi ransum yang sama. Pada perlakuan R0 tingkat konsumsi ransum sedikit yang disebabkan sedikitnya jumlah ternak dalam kandang yang akan membuat ruang gerak pada ternak semakin banyak sehingga ternak lebih banyak menghabiskan waktunya untuk bergerak, akibatnya ransum yang dikonsumsi tidak terlalu efisien.

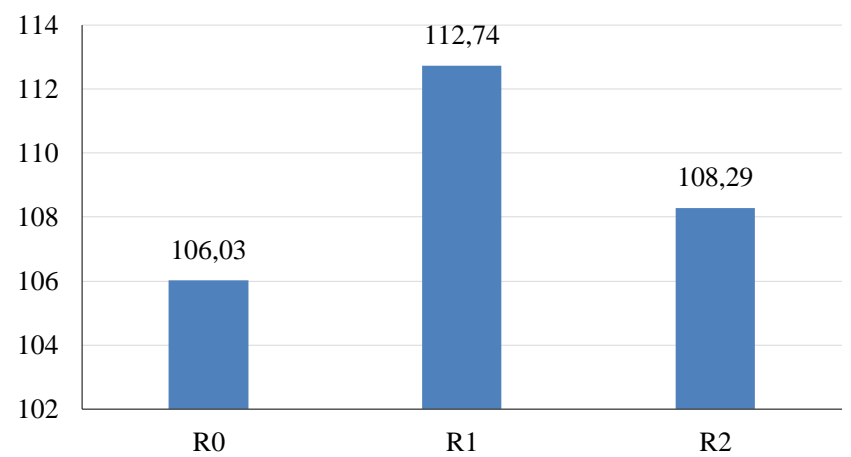

Gambar 1. Rataan Konsumsi Ransum (g/e/hr)

Tingginya tingkat konsumsi ransum pada R2 karena jumlah ternak pada perlakuan tersebut tidak terlalu banyak dan juga tidak terlalu sedikit sehingga ruang gerak yang ada di dalam kandang tidak terlalu banyak sehingga ransum yang diberikan pada ternak akan dikonsumsi dengan efisien. Menurut pendapat Wahju (2004) faktor yang dapat mempengaruhi tingkat konsumsi pakan tidak saja dipengaruhi oleh berat badan ayam, melainkan jenis kelamin, aktivitas, suhu lingkungan, kondisi lingkungan dan kesehatan ayam yang diwujudkan dengan kondisi kandang yang nyaman. Semakin hari ayam bertumbuh maka semakin banyak ransum yang dikonsumsi oleh ayam dan setiap minggu jumlah konsumsi ransum akan bertambah dari minggu sebelumnya (Fadilah, 2004).

\subsection{Pertambahan Berat Badan Harian (PBBH)}

Pertambahan berat badan merupakan perubahan ukuran yang meliputi pertambahan berat hidup, bentuk dimensi dan linier dan komposisi tubuh termasuk komponen-komponen tubuh seperti otak, lemak, tulang dan organorgan serta komponen-komponen kimia terutama air dan abu pada karkas (Soeparno, 2005). Rata-rata pertambahan berat badan harian ternak ayam broiler dapat dilihat pada Gambar 2.

Laju pertambahan berat badan ayam broiler pada perlakuan R0, R1, dan R2 tingginya PBBH terlihat pada perlakuan R1 yaitu 56,30 g diikuti oleh perlakuan R2 yaitu 56,05 g dan diikuti oleh perlakuan R0 yaitu 55,36 g. Hasil analisis sidik ragam menunjukkan bahwa pengaruh perlakuan kepadatan kandang terhadap pertambahan berat badan harian pada perlakuan R0, R1 dan $\mathrm{R} 2$ menunjukkan berbeda tidak nyata $(\mathrm{P}>0,05)$ atau dapat dikatakan bahwa antara tingkat kepadatan 4, 5 dan 6 ekor $/ \mathrm{m}^{2}$ memiliki pertambahan berat harian yang sama.

Tingginya PBBH pada perlakuan R1 dikarenakan jumlah konsumsi yang memang lebih tinggi dibandingkan R0 dan R2, pakan yang dikonsumsi tersebut dimanfaatkan dengan efisien untuk pertambahan berat badan dan sebagai akibat dari jumlah ternak dalam kandang yang tidak terlalu padat dan juga tidak terlalu sedikit sehingga ternak tidak terlalu banyak bergerak yang mengakibatkan banyaknya energi untuk pertambahan berat badan. Sedangkan pada perlakuan R0 
rendahnya $\mathrm{PBBH}$ karena masih terdapat banyaknya ruang gerak dan tingkat konsumsi yang rendah.

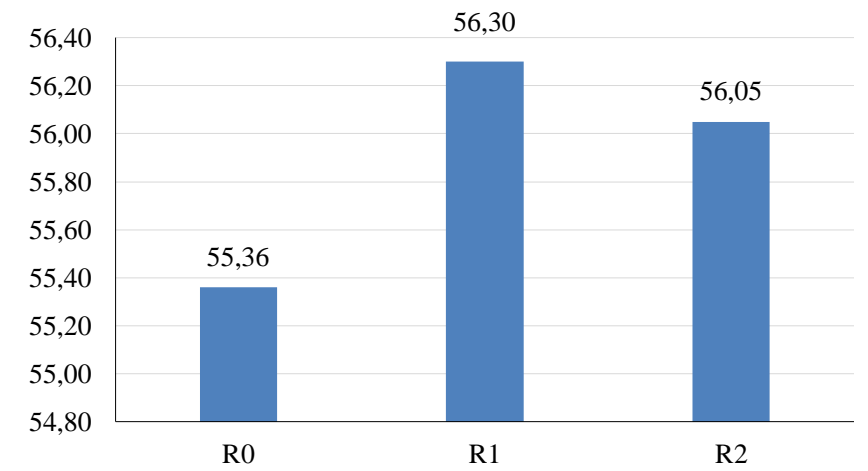

Gambar 2. Rataan Konsumsi Ransum (g/e/hr)

Semakin tinggi kepadatan pada luas kandang yang sama maka sifat perkelahian pada ternak (agonistic) akan makin tinggi (Puspani, $d k k$., 2008). Hasil penelitian ini mengindikasikan bahwa kondisi kandang pada ternak yang mendapat perlakuan $\mathrm{R}_{2}$ (6 ekor) mulai tidak nyaman karena kandang yang semakin padat akan menyebabkan kelembaban kandang yang semakin meningkat, sehingga berdampak pula pada kemampuan penampilan pertambahan berat badan terbaiknya.

\subsection{Konversi Ransum}

Konversi ransum adalah perbandingan jumlah konsumsi ransum pada satu minggu dengan penambahan berat tubuh yang dicapai pada minggu itu, bila rasio kecil berarti pertambahan berat tubuh ayam memuaskan atau ayam makan dengan efisien. Nilai konversi ransum ayam broiler dapat dilihat pada Gambar 3 .

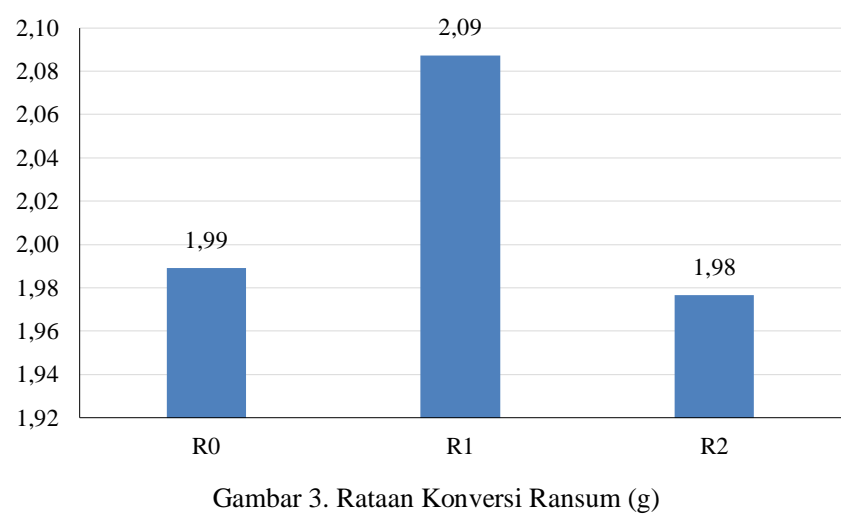

Pada Gambar 3. memperlihatkan bahwa nilai konversi ransum terbaik pada perlakuan $\mathrm{R}_{2}$ yaitu $(1,91 \mathrm{~g})$ dan diikuti oleh perlakuan $\mathrm{R}_{0}(1,99 \mathrm{~g})$ dan diikuti oleh perlakuan $R_{1}(2,09 \mathrm{~g})$. Hasil analisis sidik ragam menunjukkan bahwa pengaruh tingkat kepadatan kandang 4, 5 dan $6 \mathrm{ekor} / \mathrm{m}^{2}$ pada perlakuan $\mathrm{R}_{0}, \mathrm{R}_{1}$ dan $R_{2}$ berpengaruh tidak nyata terhadap nilai konversi ransum $(P>0,05)$. Atau dikatakan bahwa antara tingkat kepadatan kandang 4, 5 dan $6 \mathrm{ekor} / \mathrm{m}^{2}$ memiliki nilai konversi yang sama.

Faktor utama yang mempengaruhi konversi pakan adalah genetik, ventilasi, sanitasi, kualitas pakan, jenis pakan, penggunaan zat aditif, kualitas, penyakit dan pengobatan serta manajemen (Lesson, 2002). Angka konversi pakan yang kecil menunjukkan jumlah ransum yang digunakan untuk menghasilkan satu kilogram daging semakin sedikit (Kartasudjana \& Edjeng, 2006).

\section{Simpulan}

Dapat disimpulkan bahwa konsumsi ransum dan pertambahan berat badan terbaik adalah pada kepadatan kandang 5 tertinggi 5 ekor $/ \mathrm{m}^{2}$ dan konversi ransum terbaik adalah pada kepadatan kandang $6 \mathrm{ekor} / \mathrm{m}^{2}$.

\section{Pustaka}

Fadilah R. 2004. Ayam Broiler Komersial. Jakarta: Agromedia Pustaka.

Kartasudjana, R. dan S. Edjeng. 2006. Manajemen Ternak Unggas. Penebar Swadaya. Jakarta.

Lesson S. J. D. 2002. Pengaruh Penggunaan Ampas Tahu Terhadap Efisiensi Penggunaan Protein Oleh Ayam Pedaging. Jurnal Ilmiah, Semarang.

Nuriyasa, I M. dan Astiningsih, N.K. 2002. Pengaruh tingkat kepadatan ternak dan kecepatan angin dalam kandang terhadap tabiat makan ayam pedaging. Majalah Ilmiah Peternakan, Fakultas Peternakan Unud. 3 (5): 99-103.
Puspani, E. Pengaruh Tipe Lantai Kandang dan Kepadatan Ternak Terhadap Tabiat Makan Ayam Pedaging Umur 2-6 Minggu. Majalah Ilmiah Peternakan, Vol. 11 No. 1.

Rasyaf M. 2006. Beternak Ayam Pedaging. Jakarta: Penebar Swadaya.

Soeparno 2005. Teknik Membudidayakan Ayam Broiler. Penebar Swadaya.

Sudaro, Y dan A. Siriwa. 2007. Ransum Ayam dan Itik. Cetakan IX. Penebar Swadaya. Jakarta.

Wahju J. 2004. Ilmu Nutrisi Unggas. Gadjah Mada University Press, Yongyakarta 